\title{
Pengaruh Penerapan Metode Pembelajaran Syndicate Group terhadap Pemahaman Konsep Matematika Siswa SMA Negeri 14 Pekanbaru
}

\author{
Fitriyani, Darto \\ Program Studi Pendidikan Matematika, Fakultas Tarbiyah dan \\ Keguruan, UIN Sultan Syarif Kasim Riau \\ Email: darto.hafiz1@gmail.com
}

\begin{abstract}
ABSTRAK. Penelitian ini bertujuan untuk menguji ada atau tidaknya pengaruh antara pemahaman konsep matematika siswa yang belajar menggunakan metode pembelajaran Syndicate Group dengan siswa yang belajar menggunakan pembelajaran konvensional. Penelitian ini adalah penelitian Quasi Eksperimentdengan desain Pretest Posttest Control Group Design. Sampel pada penelitian ini adalah siswa kelas X SMA Negeri 14 Pekanbaru. Pengumpulan data dalam penelitian ini menggunakan dokumentasi, observasi dan tes. Untuk mengetahui hasil penelitian mengenai pemahaman konsep matematika siswa dilakukan uji $t$. Pengambilan keputusan dilakukan dengan membandingkan nilai $t_{\text {hitung }}$ dengan $\mathrm{t}_{\text {tabel }}$ baik dengan taraf signifikan $5 \%$ maupun $1 \%$ yaitu 2,00 dan 2,65 dimana nilai $t_{\text {hitung }}$ adalah 6,09. karena $t_{\text {hitung }}>t_{\text {tabel }}$, sehingga Ho di tolak dan Ha di terima. Berdasarkan hasil analisis data tersebut, diambil kesimpulan bahwa terdapat perbedaan antara pemahaman konsep matematika siswa yang belajar menggunakan metode pembelajaran Syndicate Group dengan siswa yang belajar menggunakan pembelajaran konvensional. Artinya, terdapat pengaruh metode pembelajaran Syndicate Group terhadap pemahaman konsep matematika Siswa SMA Negeri 14 Pekanbaru.
\end{abstract}

Kata kunci : pretest posttest control design, syndicate group, pemahaman konsep matematika 


\section{PENDAHULUAN}

Pemahaman konsep adalah suatu kemampuan yang harus dimiliki oleh setiap siswa karena pemahaman konsep merupakan awal dari suatu pembelajaran. Sehingga dengan adanya pemahaman, siswa akan mudah menyelesaikan suatu masalah matematika. Sebagaimana yang dikemukakan oleh Elea Tinggih matematika adalah ilmu pengetahuan yang diperoleh dengan cara bernalar yaitu lebih menekankan pada aktivitas dalam dunia rasio. Sehingga, paham terhadap konsep matematika sangat menentukan keberhasilan pembelajaran selanjutnya. Oleh karena itu, pemahaman konsep adalah suatu tujuan mendasar dalam suatu proses pembelajaran. Badan Standar Nasional Pendidikan (BSNP) menyebutkan bahwa tujuan kecakapan atau kemahiran matematika yang diharapkan dalam pembelajaran matematika mencakup pemahaman konsep, prosedur, penalaran dan komunikasi, pemecahan masalah, dan menghargai kegunaan matematika.

Berdasarkan hasil wawancara dan observasi diperoleh informasi bahwa pemahaman konsep matematika siswa SMA Negeri 14 Pekanbaru masih tergolong rendah. Hal tersebut dapat dilihat dari keseharian siswa yang masih kesulitan dalam memahami soal yang bervariasi padahal masih dalam konsep yang sama, siswa tidak bisa memberikan contoh lain yang sesuai dengan materi, serta siswa tidak dapat mengaplikasikan algoritma pemecahan masalah yang sesuai dengan prosedur.

Berdasarkan gejala-gejala yang ada, maka perlu dilakukan perbaikan dan pembaharuan dalam pembelajaran. Salah satu alternatif dalam perbaikan model pembelajaran yang sesuai dengan gejala-gejala di atas adalah menggunakan metode pembelajaran syndicate group. Metode ini merupakan metode diskusi berkelompok yang tiap kelompok mendapat tugas yang berbeda. Metode diskusi pada dasarnya adalah suatu proses bertukar informasi, pendapat dan unsur-unsur pengalaman secara teratur dengan maksud untuk mendapat pengertian bersama yang lebih jelas dan lebih cermat tentang permasalahan atau topik yang sedang dibahas. Metode ini memungkinkan dan memberikan peluang kepada siswa untuk bisa berpartisipasi aktif dalam mengumpulkan informasi dari beberapa sumber dan saat melakukan ekplorasi dan analisis, guru memberikan beberapa pertanyaan yang menuntun dan menggali pemahaman yang ada pada diri siswa sehingga siswa dapat memahami konsep yang sedang dipelajari.

Penelitian Istiarni (2012), menunjukkan adanya peningkatan prestasi belajar matematika siswa kelas VIII-A di SMP Negeri 1 Kutowinangun yang memperoleh pembelajaran menggunakan syndicate group. 


\section{METODE PENELITIAN}

Populasi dalam penelitian ini adalah seluruh siswa SMA Negeri 14 Pekanbaru. Pengambilan sampel ini dilakukan secara random kelas. Jenis penelitian ini adalah penelitian quasi eksperiment karena penulis ingin mengetahui pengaruh suatu perlakuan terhadap suatu variabel. Menurut Sugiyono (2012), penelitian ini mempunyai kelompok kontrol, tetapi tidak dapat berfungsi sepenuhnya untuk mengontrol variabel-variabel luar yang mempengaruhi eksperimen. Desain penelitian yang digunakan adalah pretestposttest control group design. Menurut Sugiyono (2012) dalam desain ini terdapat dua kelompok yang dipilih secara random, kemudian diberi pretest untuk mengetahui keadaan awal apakah ada perbedaan antara kelompok eksperimen dan kelompok kontrol. Hasil pretest yang baik bila nilai kelompok eksperimen tidak berbeda secara signifikan.

Teknik pengumpulan data yang digunakan adalah observasi berupa pengamatan aktivitas guru dan siswa selama proses pembelajaran , dokumentasi dan tes uraian. Data siswa diperoleh dari skor pretest dan skor posttest. Sebelum itu, perlu dilaksanakan uji coba soal tes untuk mengetahui validitas, reliabilitas, daya pembeda dan tingkat kesukaran soal. Instrumen yang digunakan dalam penelitian ini adalah Rencana Pelaksanaan Penelitian (RPP), Lembar Kerja Siswa, Lembar Kerja Kelompok dan soal tes untuk mengukur kemampuan pemahaman konsep matematika siswa. Prosedur dilaksanakan dengan tahapan-tahapan adalah pemberian pretest, pemberian perlakuan dengan menerapkan metode pembelajaran syndicate group dan pemberian posttest. Untuk melihat ada atau tidaknya perbedaan pemahaman konsep matematika siswa kelas eksperimen dilakukan pengujian tes pemahaman konsep matematika siswa. Pemahaman konsep matematika siswa dianalisis melalui data hasil posttest. Analisis data dilakukan dengan menggunakan uji-t.

\section{HASIL PENELITIAN DAN PEMBAHASAN}

Hasil uji hipotesis dengan menggunakan uji $t$ dilakukan pada taraf signifikansi 0,05 dengan $\mathrm{dk}=72$ diperoleh nilai $t_{\text {hitung }}=6,09$ dan $t_{\text {tabel }}=$ 2,00. Berdasarkan hasil perhitungan $t_{\text {hitung }}$ dibandingkan dengan $t_{\text {tabel }}$. Nilai $t_{\text {hitung }}=6,09$ sedangkan nilai $t_{\text {tabel }}$ dengan derajat kebebasan $(\mathrm{dk})=\mathrm{N}_{\mathrm{x}}+$ $\mathrm{N}_{\mathrm{y}}-2=37+37-2=72$ namun dalam tabel tidak terdapat $\mathrm{dk}=72$, maka dari itu digunakan dk yang mendekati 72 yaitu $\mathrm{dk}=70$. Dengan $\mathrm{dk}=70 \mathrm{jika}$ dilihat pada $t_{\text {tabel}}$, pada taraf signifikan 5\% adalah 2,00dan pada taraf signifikansi $1 \%$ adalah 2,65. Hal ini berarti bahwa $t_{\text {hitung }}>t_{\text {tabel }}$. 
Dengan demikian, dari hasil perhitungan dapat disimpulkan bahwa $\mathrm{H}_{\mathrm{a}}$ diterima dan $\mathrm{H}_{\mathrm{o}}$ ditolak yang berarti adanya perbedaan antara pemahaman konsep matematika siswa yang belajar menggunakan metode pembelajaran syndicate group dengan siswa yang belajar menggunakan pembelajaran konvensional. Hasil analisis ini mendukung rumusan masalah dan menerima hipotesis yang dirumuskan yaitu ada perbedaan antara pemahaman konsep matematika siswa yang belajar menggunakan metode pembelajaran syndicate group dengan siswa yang belajar menggunakan pembelajaran konvensional.

Setelah dilakukan analisis data, berdasarkan hasil pengujian hipotesis yang diperoleh menunjukkan bahwa terdapat perbedaan antara pemahaman konsep matematika siswa yang belajar menggunakan metode pembelajaran syndicate group dengan siswa yang belajar menggunakan pembelajaran konvensional. Adanya perbedaan menunjukkan metode pembelajaran syndicate group berpengaruh terhadap pemahaman konsep matematika siswa.Perbedaan mean kelas eksperimen dan kelas kontrol yaitu kelas eksperimen yang menggunakan metode pembelajaran syndicate group adalah 76,70 dan kelas kontrol menggunakan pembelajaran konvensional adalah 53,42 menunjukkan mean kelas eksperimen lebih tinggi dari mean kelas kontrol. Hal ini dapat disimpulkan bahwa penerapan metode pembelajaran syndicate group dalam pembelajaran matematika memiliki pengaruh positif terhadap pemahaman konsep matematika siswa, karena jika kelompok treatment lebih baik dari pada kelompok kontrol, maka perlakuan yang diberikan pada kelompok treatment berpengaruh positif (Sugiyono, 2012). Dengan adanya pengaruh positif dari penerapan metode pembelajaran syndicate group ini, berarti metode pembelajaran syndicate group merupakan metode pembelajaran yang dapat meningkatkan pemahaman konsep matematika siswa.

Pengambilan data analisis lembar observasi dilaksanakan dikelas X.1 SMA Negeri 14 Pekanbaru selama empat pertemuan. Dari hasil observasi aktivitas guru di kelas tersebut diperoleh keterangan bahwa rata-rata aktivitas guru adalah 81,225 \% terlihat juga pada total skor dari pertemuan awal sampai pertemuan akhir mengalami peningkatan. Artinya pelaksanaan pembelajaran menggunakan Syndicate Group oleh aktivitas guru menunjukkan peningkatan. Hal yang sama juga ditunjukkan oleh aktivitas siswa dalam pembelajaran, rata-rata aktivitas siswa adalah $78,57 \%$ terlihat juga pada total skor dari pertemuan awal sampai pertemuan akhir mengalami peningkatan. Artinya pelaksanaan pembelajaran menggunakan Syndicate Group oleh aktivitas siswa menunjukkan peningkatan. 
Berikut ini ditunjukkan beberapa contoh jawaban yang diberikan oleh siswa dalam menjawab soal yang diberikan.

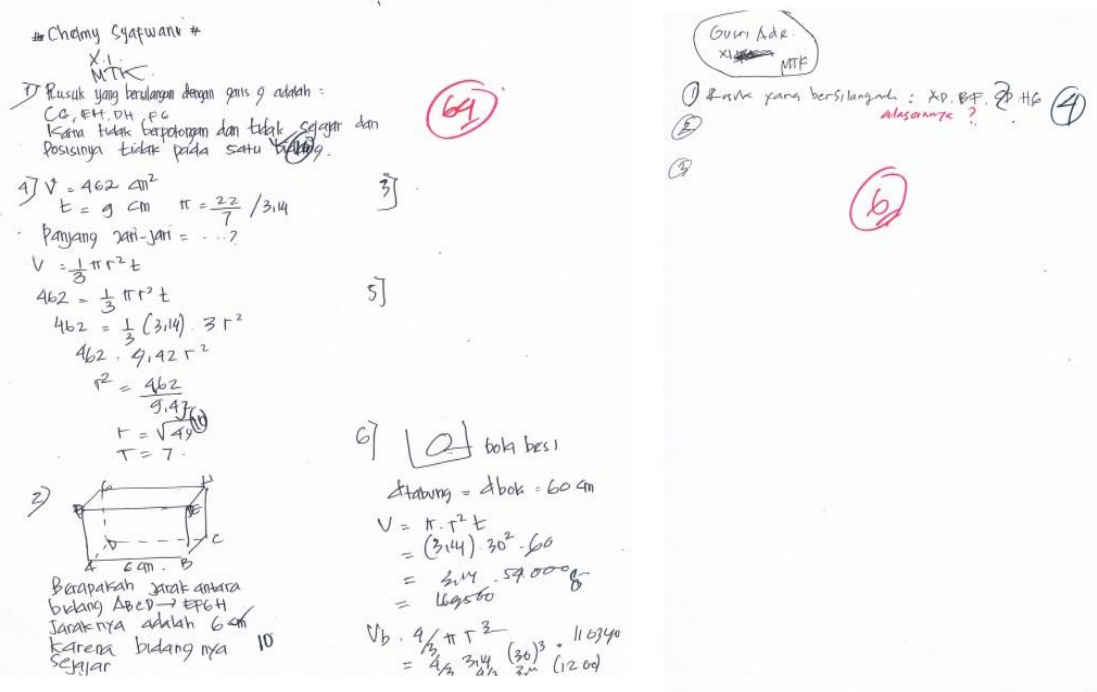

Gambar 1. Contoh Jawaban Pretes Kelas Ekperimen

Berdasarkan hasil nilai pretest pada kelas eksperimen, terlihat bahwa pemahaman konsep matematika siswa dalam menyelesaikan soal matematika masih tergolong rendah. Hal ini dapat diperoleh dari nilai tes awal siswa. Sebagian besar banyak siswa yang tidak bisa menjawab soal yang diberikan oleh peneliti. Seperti yang dilakukan oleh salah seorang siswa dalam menjawab soal, masih memiliki nilai terendah terkait dengan soal pemahaman konsep matematika. Banyak soal yang tidak dijawab artinya tidak adanya usaha dalam menjawab soal. Hanya satu dari enam soal yang adanya usaha tetapi masih saja salah interpretasi pada sebagian kecil soal dan perencanaan dan penyelesaian yang tidak sesuai karena yang dijawab hanya bagian rusuk-rusuk yang berpotongan sedangkan alasannya mengapa bisa berpotongan secara umum tidak dilampirkan, yaitu pada soal no 1. Dan soal nomor 3, 4, 5, dan 6 tidak ada usaha dan tanpa jawab, hanya memperoleh skor 4 dari skor tertinggi 60.

Sedangkan untuk siswa yang mendapatkan nilai tertinggi pada uji pretest hanya bisa menjawab 3 soal dari 6 soal dengan sangat baik, memperoleh skor 38 , artinya dalam pemahaman soal interpretasinya bagus, 
prosedur penyelesaiannya tepat tanpa kesalahan aritmatika dan dalam menjawab soal pun penyelesaiannya sudah benar. Sedangkan soal selebihnya masih banyak kekurangan dalam pemahaman, penyelesaian dan dalam menjawab soal. Masih terdapat soal yang sama sekali tidak dijawaboleh siswa.

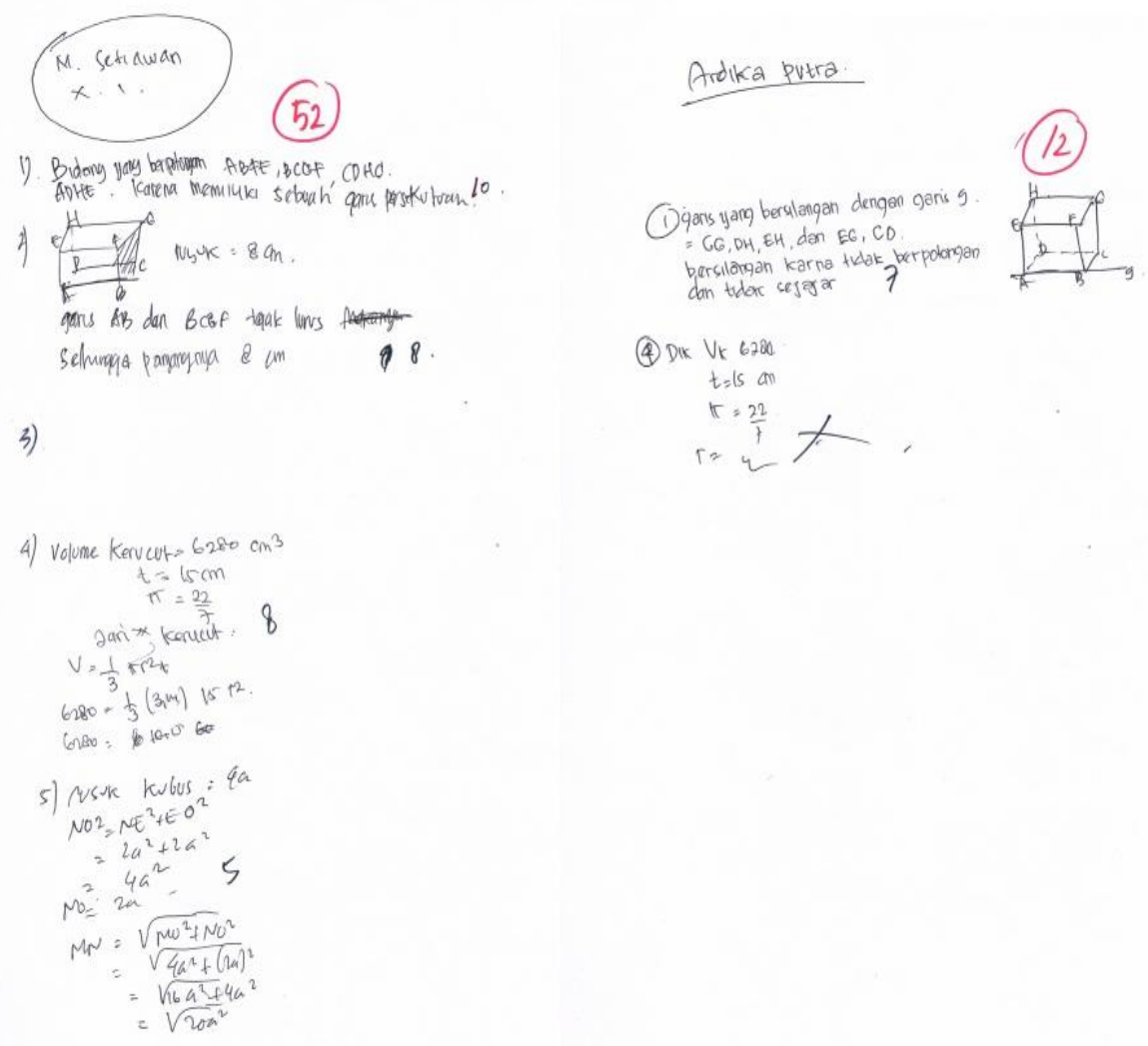

Gambar 2. Contoh Jawaban Pretes Kelas Kontrol

Berdasarkan hasil nilai uji pretest pada kelas kontrol, pemahaman konsep siswa pun terlihat masih rendah. Ini menyatakan bahwa kemampuan pemahaman antara siswa kelas eksperimen dan kelas kontrol berdasarkan data awal sama. untuk siswa yang mendapatkan nilai terendah memiliki skor 
7 . Hanya 1 soal yang dijawab dengan sangat baik, sedangkan soal selebihnya ada yang dijawab tetapi masih kurang dalam penyelesaian, bahkan ada soal yang siswa tidak ada sama sekali usahanya dalam menjawab.

Sedangkan untuk siswa yang memiliki nilai pretest tertinggi pada kelas kontrol yaitu mendapatkan skor 38, dari keenam soal hanya dua soal yang dapat dijawab dengan sempurna. meskipun demikian, Tetapi masih ada usaha menjawab semua soal meskipun ke 4 soal lainnya tersebut tidak dijawab dengan sempurna.

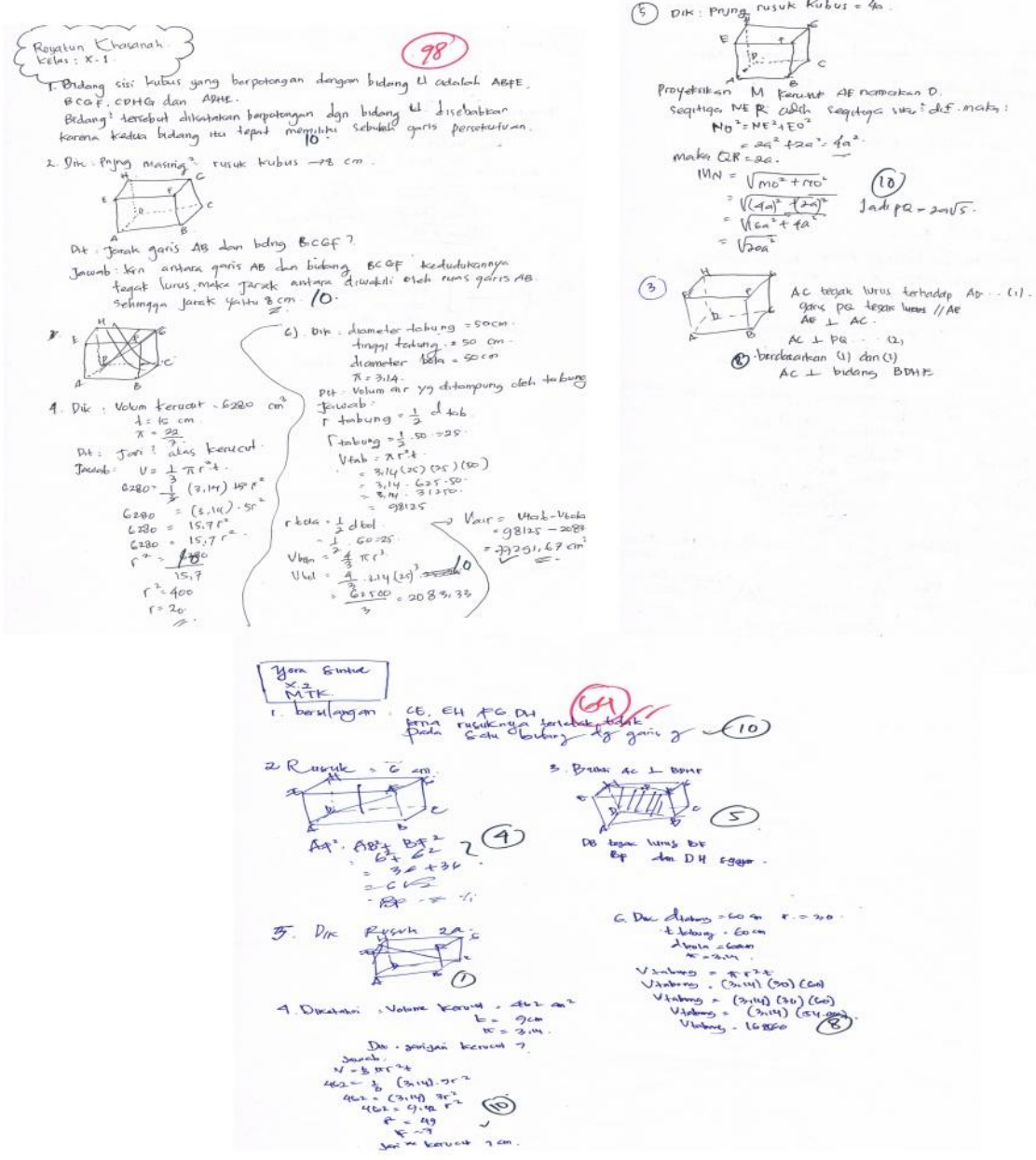

Gambar 3. Contoh Jawaban PosttesKelas Eksperimen 
Berdasarkan hasil nilai posttest yang diperoleh dari kelas eksperimen terlihat adanya peningkatan pemahaman konsep siswa setelah adanya perlakuan. Seperti nilai tertinggi yang diperoleh oleh siswa yang bernama royatun khasanah mendapatkan skor 59 dan hampir mencapai skor yang sempurna. Hanya saja terdapat satu soal yang mempunyai kesalahan sedikit dalam menjawab soal.

Untuk siswa yang mendapatkan nilai postest terendah pada kelas kontrol tetap mengalami peningkatan pemahaman konsep dibandingkan sebelum perlakuan, yaitu mendapatkan skor 31. Menjawab 1 soal dengan sempurna sedangkan soal selebihnya ada yang prosedurnya benar, tetapi masih terdapat kesalahan, bahkan ada jawaban yang salah yang diakibatkanprosedur penyelesaian yang tidak tepat.

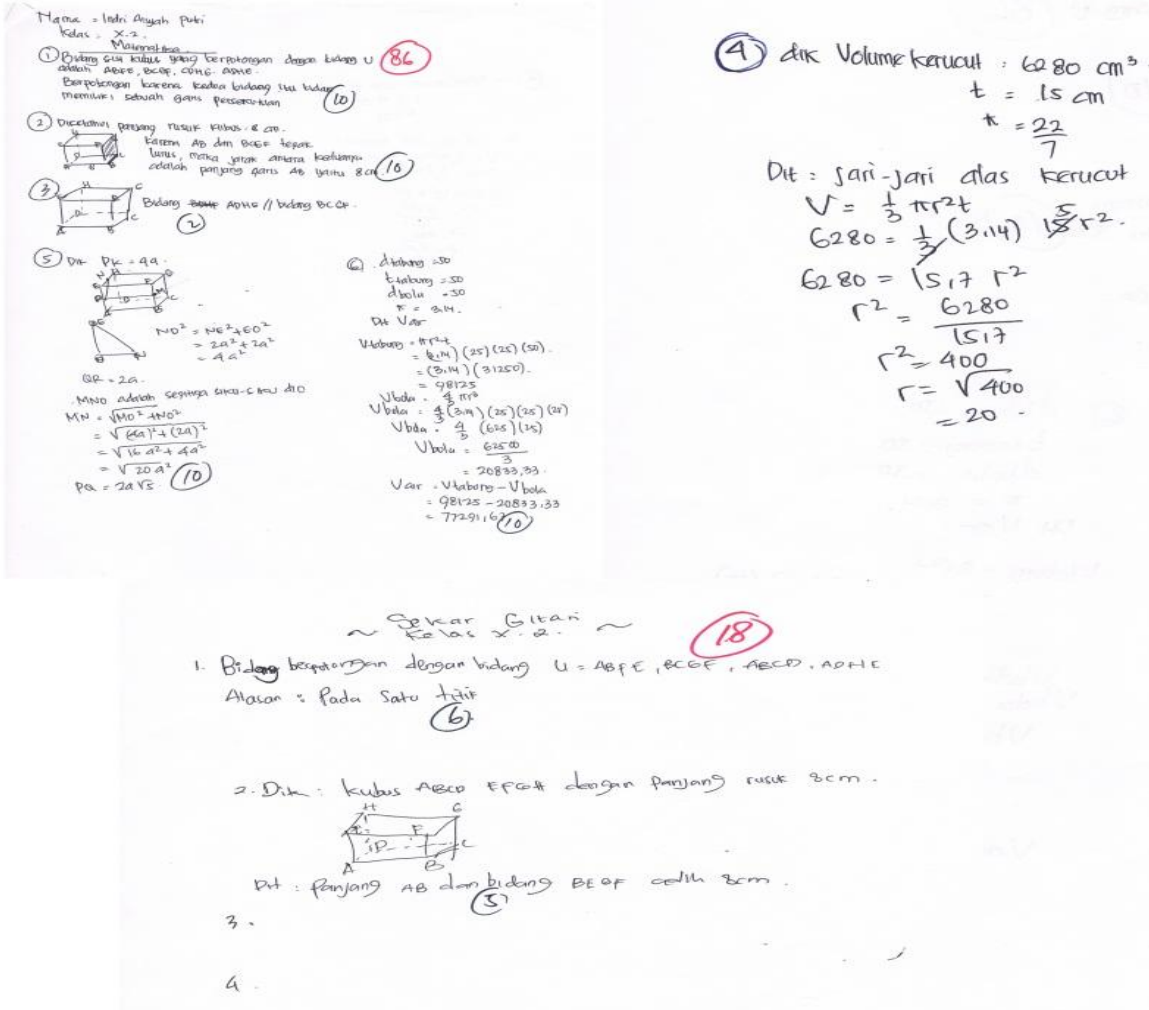

Gambar 4. Contoh Jawaban Posttest Kelas Kontrol 
Untuk hasil nilai postest yang didapat pada kelas kontrol, skor tertinggi yang diperoleh pada kelas kontrol yaitu 52. Dapat menjawab 5 soal dengan sangat baik, dan 1 soal yang salah interpretasi pada sebagian soal.

Skor yang diperoleh dari siswa yang memiliki nilai terendah, yaitu 11 . Hanya bisa menjawab 2 soal dari 6 soal yang disediakan, tetapi tetap kedua soal tersebut belum sempurna jawabannya, masih ada jawabannya yang tidak selesai dikerjakan dan prosedurnya yang masih terdapat kesalahan.

\section{KESIMPULAN}

Berdasarkanhasil penelitian dan pembahasan yang dilakukan, dapat diambil kesimpulan bahwa terdapat perbedaan antara pemahaman konsep matematika siswa yang belajar menggunakan metode pembelajaran syndicate group dengan kelas kontrol yang belajar menggunakan pembelajaran konvensional. Adanya perbedaan tersebut dapat dilihat dari mean kelas eksperimen yaitu 76,70, dimana rata-rata nya lebih tinggi dari mean kelas kontrol yaitu 53,62. Hal tersebut menunjukkan bahwa penerapan metode pembelajaran syndicate group dalam pembelajaran matematika lebih baik dari pembelajaran konvensional. Artinya dari adanya perbedaan tersebut, maka terdapat pengaruh yang positif penerapan metode pembelajaran syndicate group terhadap pemahaman konsep matematika siswa.

\section{DAFTAR PUSTAKA}

Istiarni, A. (2012). Penerapan Syndicate Group dalam Upaya Meningkatkan Pretasi Belajar Matematika Siswa kelas VIII-A di SMP Negeri 1 Kutowinangun Universitas Negeri Semarang. [Online]. Tersedia:http://journal.unnes.ac.id/nju/index.php/DP/article/.../342

Sugiyono. (2012). Metode Penelitian Pendidikan Pendekatan Kuantitatif, Kualitatif, dan $R \& D$. Bandung: Alfabeta. 